\title{
The Effect of Reminiscence Therapy on Increasing Cognitive Function in The Elderly
}

\author{
Akhmad Yanuar Fahmi \\ Pamungkas \\ STIKES Banyuwangi \\ Yanuarfahmi20@gmail.com \\ Rima Ambarwati \\ STIKES Banyuwangi \\ rimaambarwatil IDes@gmail.com
}

\author{
Sholihin \\ STIKES Banyuwangi \\ sholihin@stikesbanyuwangi.ac.id
Essy Sonontiko Sayekti
STIKES Banyuwangi \\ essy.stikesbwi@gmail.com
}

\begin{abstract}
Reminiscence therapy is proven to be effective in reducing cognitive disorders among the elderly. However, there are some differences in the method of giving reminiscence therapy, so that further research is needed to determine these differences. This study aimed to determine differences in the effectiveness of mindfulness reminiscence in reducing cognitive disorders in the elderly. This study used a pre-post test quasi-experimental design with a control group. The sample consisted of the elderly at Tresna Werdha Orphanage Glenmore $(n=60)$ who were divided into 2 groups, namely the intervention group $(n=30)$ and the control group $(n=30)$. Data collection of cognitive disorders was taken from the component of cognitive disorders questions on the MMSE questionnaire. Data analysis used paired and unpaired t-test. The results showed that reminiscence therapy was effective in reducing cognitive disorders in the elderly.
\end{abstract}

Keywords: cognitive, elderly, reminiscence therapy.

Received 23 August 2021/Accepted 25 October 202I @Author all rights reserved

\section{Introduction}

Cognitive changes, dementia and cognitive abilities are profoundly affected by aging age (Moka et al., 2015). It is characterized by a decline in the brain in thought, out of focus, a tendency to forget, unable to learn in a long time. The signs above are normal things experienced by the elderly because it is a physiological process (Haqi et al., 2019).

In 2005 in Asia Pacific there were 4.3 million events of cognitive decline which will increase to 19.4 million per year by 2025 . The prevalence in America reaches $19.8 \%$ at the age of $65-74$, in Taiwan reaches $27.5 \%$ at the age of $75-84$, and in China reaches $9.9 \%$ to $46.7 \%$ in the age range $60-108$ (World Economic Forum (WEF) et al., 20I8). Alzheimer's Disease International in 2014 stated that 
the estimated prevalence of cognitive decline in Indonesia in 2015 was I.033 million, in 2030 it was I.894 million and in 2050 it was 3.979 million (Prince et al., 20 I4). The decline in cognitive function can cause several effects depending on the stage of cognitive decline experienced by the elderly. This study is in accordance with research conducted by Gu et al., 2018, with 53 respondents and it was concluded that almost half of the cognitive functions in the elderly experienced changes (Chaouali \& Souiden, 2019). Research was also conducted by I Gusti Ayu Harry Sundariyati et al (2014) with 84 respondents, stating that 46 people or $54.8 \%$ experienced changes in cognitive function (Ma et al., 2017). Another similar study conducted by Prawesti and stated that of the 30 respondents, as many as 8 people experienced mild cognitive decline, 16 people experienced moderate cognitive decline and 5 people experienced severe cognitive decline (Galbraith \& Brown, 2010). Based on a preliminary study conducted at the Integrated Service Unit (UPT) of the Tresna Werdha Orphanage (PSTW) Banyuwangi, it was found that 9 out of 10 elderly with severe cognitive disorders were 6 elderly, moderate cognitive disorders were 3 elderly and did not experience cognitive disorders was one elderly.

One of the impacts of decreased cognitive function is a decrease in memory ability, lead to difficulty to remember short term memory, decreased understanding and capturing information, difficulty solving problems, difficulty making decisions (Haqi et al., 2019). At a more advanced stage, more real problems will be found, including the elderly will have difficulty in carrying out activities of daily life, experience changes in behavior, perform inappropriate behavior in society and are very dependent on others (Schulz \& Eden, 2016).

Factors that affect the cognitive function of the elderly are age, the ability to regenerate the brain, inadequate vascularization to the brain and hormones that can cause a decreased quality of life, functional status that is not optimal and affect feelings of happiness and creativity (Farhud et al., 2014). The decline in cognitive function has a negative impact on the elderly, so nurses as health workers can use therapeutic methods to reduce cognitive function disorders in the elderly. One method of therapy that can be used is memory therapy (reminiscence therapy).

Reminiscence is a technique used to remember and talk about someone's life (Thomas \& Briggs, 2016). This therapy is used for the elderly who experience cognitive disorders, loneliness and psychological recovery (Redulla, 2019). Thomas (2016) and Redulla (2019) said that reminiscence 
therapy can be given to the elderly individually, in families or in groups. Several studies stated that reminiscence therapy can overcome cognitive disorders, stress and many other psychosocial diseases (Yanuar \& Pamungkas, 2019; Murman, 2015).

Reminiscence therapy is one of the efforts to improve the health status of the elderly. Several studies recommended this therapy in overcoming cognitive disorders. Several other studies have stated that Reminiscence therapy only affects Alzheimer's in an elderly person (Lök et al., 2019), while in this study Reminiscence therapy is very influential on depression in the elderly. in previous studies Reminiscence therapy has been applied to elderly people who experience depression and it is proven that there is an effect on reducing depression but in this study (Chin, 2007), the number of samples was too small, namely, 30 respondents so that there were biased results in this study, researchers involved 60 respondents so that they could get maximum results. Reminiscence therapy is the best therapy in overcoming cognitive disorders because this type of therapy is very suitable for the character of the elderly who are easy to tell stories about happy pasts.

\section{Method}

Research design

This study is a quasi experimental with a pretest and post-test control group design, by measuring before and after giving therapy to reminiscence therapy group and the control group.

\section{Participant}

This research was conducted in January 2021 for 7 days. The population in this study were all the elderly at Tresna Werdha Orphanage (PSTW) Glenmore as many as 100 people. The first step was the researcher explained the aims and objectives of the research. After that, the researcher distributed a inform consent sheet about the willingness to be a respondent. Then, the researcher explained about the research process, starting from filling out the questionnaire for those who were able to fill it out, and if there were respondents who were unable to fill it out, they will be helped by researcher. 
Sampling procedures

Sampling in this study used a purposive sampling method using Mini Mental Status Exam (MMSE) questionnaire, it was found that 60 elderly people who fit the inclusion criteria, namely the elderly who live in PSTW Glenmore Banyuwangi, have moderate to severe cognitive impairment and are willing to be respondents. The sample size was divided randomly into 2 groups, namely the treatment group using Reminiscence Therapy $(n=30)$ and the Control treatment group $(n=30)$.

\section{Instrument}

The instrument used to measure the cognitive of the elderly is the Mini Mental Status Exam with 5 question criteria. The first is time orientation (the researcher asked the respondent about the day, month and year), the second is place orientation (the researcher asked the respondent about the country, orphanage and district), the third is registration and memory (the researcher asked about objects such as tables, chairs and pots and then the respondent repeat), fourth is attention and calculation (Asked the respondent to count from 100 then subtracted 7 to 3 levels). The fifth is Language by asking the respondent about the object (while showing the object), Ask the respondent to follow the following command which consists of 3 steps. Take the paper in the researcher's hand, fold it in half and place it on the floor. Researchers have conducted the validity and reliability test of the questionnaire. The validity test of questionnaire was conducted on 20 respondents who fit the research criteria but were not included in the research respondents. The validity test of the instrument in this study used Pearson's product moment $(r)$ by comparing the score of each question item with the total score of all questions and to determine the significance value of the relationship of each question, then $r$ count value is compared with the $r$ table value. The question is declared valid if $r$ count is greater than $r$ table with a significance value of $5 \%, r$ table is known to be 0.444 . The results of the Pearson test showed that from 5 questions, the $r$ value was $>0.444$, so all questions were declared valid. The reliability test of this research questionnaire used Cronbach's alpha with the provision that if the alpha value is closer to $I$, the reliability value of the research instrument is higher and if $r$ alpha is more than $r$ table, then the instrument is declared reliable. Based on the results of Cronbach's alpha test, it was known that the reliability coefficient value was $r=0.82$ or $r>0.444$ so that the questionnaire was declared reliable. 


\section{Data analysis}

In the first data analysis, researchers looked for differences in cognitive scores in each group before and after treatment using paired t-test. In the second data analysis, researchers looked for differences in cognitive scores after treatment between Reminiscence Therapy and the Control group using an unpaired t-test.

\section{Results}

\section{Univariate Analysis}

The results of the univariate analysis in this study are shown in table I about the distribution of respondents based on age and gender which is shown with frequency and percentage.

\section{Table I}

Caracteristics of elderly respondents

\begin{tabular}{ll}
\hline \multicolumn{1}{c}{ Data } & $\mathrm{n}$ \\
\hline Gender : & \\
Male & 25 \\
Female & 35 \\
\hline Age (Years Old) : & \\
$50-59$ & 18 \\
$60-69$ & 12 \\
$70-79$ & 10 \\
$80-89$ & 15 \\
$>90$ & 5 \\
\hline
\end{tabular}

Based on Table I above, it is known that the distribution of respondents based on age is mostly in the age of 50-59 years as many as 18 respondents (30\%), based on gender, most of them are female as many as 35 respondents (52\%).

Table 2

Differences in the cognitive values of elderly before and after Reminiscence Therapy and Control

\begin{tabular}{ccccccc}
\hline & M pre & M Post & SD Pre & SD Post & Difference & P-Value \\
\hline Reminiscence & 30.61 & 28,39 & 2,97 & 5,81 & 9.22 & 0,000 \\
Control & 30,72 & 20,39 & 2.82 & 3,55 & 5.12 & 0.512 \\
\hline
\end{tabular}


The table above explained that the results of the paired $T$ test between the values before and after Reminiscence Therapy obtained the mean \pm SD cognitive in the elderly before treatment was 30.61 \pm 2.97 and the mean \pm SD cognitive value of the elderly after treatment was $28.39 \pm 5.8 \mathrm{I}$. It is known that there is a difference with a difference of 9.22 . The results of further analysis obtained $p$ value $=0.000$ which means $P<0.05$. Cognitive values before and after the control treatment showed that mean \pm SD cognitive value of the elderly before treatment was $30.72 \pm 2.82$ and mean value of cognitive $\pm S D$ of the elderly after treatment was $26.39 \pm 3.55$. It is known that there is a difference with a difference of 3.33. The results of further analysis obtained $p$ value $=0.5 \mathrm{I} 2$, which means $P$ $<0.05$. This shows that there is a significant difference between cognitive before and after being given the Reminiscence Therapy intervention and not being given the intervention.

\section{Table 3}

Differences in the Effect of Reminiscence Therapy and Control Group on Cognitive in Elderly

\begin{tabular}{ccccc}
\hline & Mean & SD & Difference & P-Value \\
\hline Reminiscence & 21.39 & 5,81 & $-6,38$ & 0.001 \\
Control & 26,39 & 3,55 & &
\end{tabular}

Table 3. explained that the result of unpaired $T$ test was known that there is a significant difference in the mean cognitive value of the elderly between the two groups, namely the intervention group has a mean $\pm S D$ cognitive value of elderly was $21.39 \pm 5.8 \mathrm{I}$ and the control group has a cognitive mean $\pm S D$ value of Iderly was $26.39 \pm 3.55$, it was known that there was a difference with a difference value of -6.38 . The results of further analysis obtained $p$ value $=0.001$ which means $p<0.05$. This showed that there was a significant difference in the mean cognitive score between the intervention group and the control group.

\section{Discussion}

The results of the reminiscence therapy research has proven to have a significant effect on cognitive changes in the elderly. Based on the results of the study, most of them were at the age of 50-59 years as many as 18 respondents (30\%), based on gender, most of them were female as many as 35 respondents (52\%). 
Increasing age will cause anatomical changes, especially in the neurological system such as shrinkage of nerve cells in the brain so that it can cause a decrease in cognitive function. Getting older, the weight of brain decreases by $10 \%$, the number of neurons will decrease about 100,000 cells per day which is at risk of experiencing brain shrinkage (Chaouali \& Souiden, 2019). The results of another study stated that dementia will arise from 60 years and will increase every 5 years because of increasing number of neurons in the brain becoming tangled (neurofibrillary tangles) and appearance of various plaques in the blood. Women are more at risk for cognitive impairment, because of the high life expectancy in women (Huang \& Zhao, 2020).

Menopause in the elderly will cause a decrease in the estrogen hormone in the body. The estrogen hormone has a very important function, one of its functions is for memory in the brain (Farhud et al., 20l4). Women have one of the estrogen receptors in the brain, namely the hippocampus, which has a very important function in the process of memory formation. Women who are menopause experience a decrease in the estrogen hormone which causes forgetfulness or memory loss (Girardeau et al., 2020). The estrogen hormone also has protective characteristic of atherosclerosis that inhibits lipolysis (Kwilasz, 2016). Decreased of estrogen hormone is at risk of causing lipolysis which can trigger the spread of cholesterol in the blood which is at risk of atherosclerosis. Atherosclerosis causes reduced blood flow to the brain which makes difficult to concentrate and easy to forget (Soliman, 2018). Decreased of cognitive function occurs in the elderly aged over 60 years, and is more common in women than men because of hormones, namely menopause, it will cause a decrease in the estrogen hormone in the body (Murman, 2015). The results also showed that most of the elderly had moderate cognitive disordes. An exploratory study stated that the average elderly suffer from moderate cognitive disordes caused by stressors, and their past (Eshkoor et al., 2015). A good past will cause the elderly to have good cognitive because they always reflect on the good past and good self ideal (Soleimani et al., 2018).

Reminiscence therapy-based therapy in reducing cognitive disorders (Chaouali \& Souiden, 2019). Duru Așiret \& Kapucu, (2016) in their literature study said that 60 studies said Reminiscence Therapy-based interventions were effective for reducing cognitive disorders in the elderly, but there were significant differences in effectiveness levels. This is affected by the frequency, duration, and differences in the method of giving. This opinion is by the results of this study, where the results of the unpaired $T$-test are known to have a significant difference in the mean \pm SD Cognitive Elderly 
between the two groups, namely the Intervention group has a mean \pm SD Cognitive Elderly value was $21.39 \pm 5.8 \mathrm{I}$ and the Control group has The mean \pm SD cognitive value for the elderly was $16.39 \pm 3.55$, which is known to have a difference with the Mean Difference \pm SD value of $-6.38 \pm 1.81$. The results of further analysis obtained $p$-value $=0.001$ which means $p<0.05$. It showed that there was a significant difference in the mean cognitive score between the intervention and control groups.

\section{Limitation of The Study}

The limitation of this study is it was carried out during a pandemic which caused Reminiscence Therapy interventions is not optimal because they had to strictly adhere to health protocols. Another limitation is the control group cannot be treated after a series of studies because of policies

\section{Conclusions}

Reminiscence Therapy is effective in reducing cognitive disorders in the elderly. There is a difference between respondents who were given Reminiscence Therapy and the Control group on the decline of cognitive disorders in the elderly. Reminiscence Therapy has been proven to reduce cognitive disorders compared to the control group who did not receive the intervention. Suggestions for the nursing profession, especially Gerontic nurses, in carrying out nursing care, Reminiscence Therapy can be used as an intervention and evidence based practice in overcoming.

\section{References}

Chaouali, W., \& Souiden, N. (2019). The role of cognitive age in explaining mobile banking resistance among elderly people. Journal of Retailing and Consumer Services, 50(xxxx), 342-350. https://doi.org// 0.10 / 6/j.jretconser.2018.07.009

Chin, A. M. H. (2007). Clinical effects of reminiscence therapy in older adults: A meta-analysis of controlled trials. Hong Kong Journal of Occupational Therapy, I 7(I), I0-22. https://doi.org/l 0.1016/S1569-I86I(07)70003-7

Duru Așiret, G., \& Kapucu, S. (2016). The effect of reminiscence therapy on cognition, depression, and activities of daily living for patients with alzheimer disease. Journal of Geriatric Psychiatry and Neurology, 29(I), 3 I-37. https://doi.org// 0. I I 77/089/9887/5598233

Eshkoor, S. A., Hamid, T. A., Mun, C. Y., \& Ng, C. K. (20I5). Mild cognitive impairment and its management in older people. Clinical Interventions in Aging, 10, 687-693.

https://doi.org// 0.2 I 47/CIA.S73922

Farhud, D. D., Malmir, M., \& Khanahmadi, M. (2014). Happiness \& health: The biological factors- 
systematic review article. Iranian Journal of Public Health, 43(I I), I 468-I 477.

Galbraith, N. D., \& Brown, K. E. (20/0). Quantitative systematic review. https://doi.org/ / 0. I / / / /j. I 365 2648.2010.05549.x

Girardeau, J. C., Blondé, P., Makowski, D., Abram, M., Piolino, P., \& Sperduti, M. (2020). The impact of state and dispositional mindfulness on prospective memory: A virtual reality study. Consciousness and Cognition, 8I(February), 102920. https://doi.org//0.1016/j.concog.2020.102920

Gu, L., Chen, J., Gao, L., Shu, H., Wang, Z., Liu, D., Yan, Y., Li, S., \& Zhang, Z. (20/8). Cognitive reserve modulates attention processes in healthy elderly and amnestic mild cognitive impairment: An event-related potential study. Clinical Neurophysiology, I29(I), 198-207. https://doi.org// 0.1016/j.clinph.2017.10.030

Haqi, M. H., Misbahatul, E., \& Bahiyah, K. (20/9). Gambaran status mental (stres, kecemasan, dan depresi). Psychiatry Nursing Journal, I(2), 29-35.

Huang, Y., \& Zhao, N. (2020). Generalized anxiety disorder, depressive symptoms and sleep quality during COVID-19 outbreak in China: a web-based cross-sectional survey. Psychiatry Research, 288, I I 2954. https://doi.org//0.10 I 6/j.psychres.2020.I I 2954

Kwilasz, A. J. (2016). 乳鼠心肌提取 HHS Public Access. Physiology \& Behavior, I76(I), I39-I 48. https://doi.org//0.1016/bs.ctdb.2016.12.005.Estrogen

Lök, N., Bademli, K., \& Selçuk-Tosun, A. (2019). The effect of reminiscence therapy on cognitive functions, depression, and quality of life in Alzheimer patients: Randomized controlled trial. International Journal of Geriatric Psychiatry, 34(I), 47-53. https://doi.org// 0. I002/gps.4980

Ma, C., Yin, Z., Zhu, P., Luo, J., Shi, X., \& Gao, X. (2017). Blood cholesterol in late-life and cognitive decline: A longitudinal study of the Chinese elderly. Molecular Neurodegeneration, I2(I), I-9. https://doi.org// 0.I I86/s/3024-0/7-0/67-y

Moka, S., Pande, M., Rani, M., Gakhar, R., Sharma, M. M., Rani, J., Bhaskarwar, A. N., Autelitano, F., Giuliani, F., Qureshi, M. N., Ghosh, S., Shiying, L., Wingtat, H., Zhen, L., Harvey, J., Kendall, A., Saboori, A., Sonar, S. S., Kategaonkar, A. H., ... Ding, G. K. C. (20I5). No 主観的健康感を中 心とした在宅高齢者における健康関連指標に関する共分散構造分析Title. Construction and Building Materials, 4(I), I-8.

http://www.ncbi.nlm.nih.gov/pubmed/I 7289255\%0Ahttp://dx.doi.org// 0.10 I 6/j.jclepro.20 I I.I 0.008 \%0Ahttp://www.uwaba.or.tz/National_Road_Safety_Policy_September_2009.pdf\%0Ahttp://dx.doi.org/ 10.1016/j.resconrec.201 I.03.010\%0Ahttp://dx.doi.org/l0.1016/j.pecs.20

Murman, D. L. (20I5). The impact of age on cognition. Seminars in Hearing, 36(3), III-I II. https://doi.org//0.1055/s-0035-1555//5

Prince, M., Albanese, E., Guerchet, M., \& Prina, M. (20I4). World alzheimer report 2014 dementia and risk reduction an analysis of protective and modifiable factors EXECUTIVE SUMMARY dr Maëlenn Guerchet dr Matthew prina. www.daviddesigns.co.uk

Redulla R. (2020). Reminiscence therapy for dementia. Issues Ment Health Nurs, 4 I (3), 265-266. doi: 10.1080/01612840.2019.1654572. Epub 2019 Nov I2. PMID: 31714840.

Schulz R, \& Eden J, (20I6). Families caring for an aging America. Washington (DC): National 
Academies Press (US); 2016 Nov 8. Available from:

https://www.ncbi.nlm.nih.gov/books/NBK39640I/ doi: 10.17226/23606

Soleimani, R., Shokrgozar, S., Fallahi, M., Kafi, H., \& Kiani, M. (20I8). An investigation into the prevalence of cognitive impairment and the performance of older adults in Guilan province. Journal of Medicine and Life, I I(3), 247-253. https://doi.org/ / 0.25 I 22/jml-20 I 8-00 I 7

Soliman, G. A. (2018). Dietary cholesterol and the lack of evidence in cardiovascular disease. Nutrients, 10(6), 780. https://doi.org//0.3390/nul0060780

Thomas, L., \& Briggs, P. (2016). reminiscence through the lens of social media. Frontiers in Psychology, 7(JUN), I-I I. https://doi.org/l0.3389/fpsyg.2016.00870

World Economic Forum (WEF), Mnif, S., Feki, C., Abdelkafi, I., Terziyan, V., Gryshko, S., Golovianko, M., Krousie, C., Kapeliushnikov, R., Personal, M., Archive, R., Henk, L. M., Kyvik, H., Analysis, E. P., Affairs, I., Board, E., Affairs, I., Smolny, W., Pierse, R. G., ... Vivarelli, M. (2018). No 主観的健康感を中心とした在宅高齢者における 健康関連指標に関する共分 散構造分析Title. Russian Journal of Economics, 48(2), I 23-154.

https://www.academia.edu/38922036/The_Integration_of_Technology_into_English_Language_Teac hing_The_Underlying_Significance_of_LMS_in_ESL_Teaching_despite_the_Ebb_and_Flow_of_Imple mentation?email_work_card=view-paper\%250Ahttps://doi.org// 0.I /55/20/6/3/59805\%25

Yanuar, A., \& Pamungkas, F. (2019). Hubungan dukungan sosial dengan tingkat stres pada warga binaan pemasyarakatan perempuan di lembaga pemasyarakatan. Journal of Holistic Nursing and Health Science, 2(2), 42-47. 